\section{Congenital Morphea: Two Case Reports}

\author{
Guerra $\mathrm{AB}^{1 *}$, Almeida $\mathrm{TL}^{1}$, Lara $\mathrm{PE}^{2}$ and Tapadinhas $\mathrm{MC}^{2}$ \\ ${ }^{1}$ Department of Pediatrics, Hospital do Espirito Santo de Évora, Évora, \\ Portugal \\ ${ }^{2}$ Department of Dermatology, Centro Hospitalar Universitário Lisboa Norte, \\ Hospital de Santa Maria, Lisbon, Portugal
}

\begin{abstract}
Congenital morphea is a rare and underestimated form of localized scleroderma that presents at birth. From the five known subtypes, linear and plaque morphea are the most common and benign forms and are both described in these cases. Extracutaneous manifestations are rare. Prognosis is usually good. Long-term followup is important to prevent complications during growth. Spontaneous resolution may occur and mild forms have a great response to topical corticosteroids or calcineurin inhibitors.
\end{abstract}

Keywords: Congenital morphea; Localized scleroderma; Linear; Plaque

\section{Introduction}

Localized scleroderma, also called morphea, is a connective tissue disease, presenting with cutaneous sclerosis and usually a benign and self-limited evolution. There are five subtypes of morphea: Plaque, linear, generalized, pansclerotic, and mixed [1]. Linear morphea is the most frequent form of scleroderma in childhood and the face may be involved as well as the trunk and limbs. Plaque morphea is the most benign form with few discrete plaques confined to one to two anatomic areas [1]. Acquired morphea is the most frequent form of localized scleroderma and the congenital form has been reported rarely $[1,2]$. This article reports two infants with superficial cutaneous sclerotic lesions from birth, histologically compatible with congenital morphea.

*Corresponding author: Guerra AB, Department of Pediatrics, Hospital do Espírito Santo de Évora, Évora, Portugal, Tel: +351 967985208; E-mail: a.bentoguerra@gmail.com

Citation: Guerra AB, Almeida TL, Lara PE, Tapadinhas MC (2020) Congenital Morphea: Two Case Reports. J Neonatol Clin Pediatr 7: 062.

Received: December 23, 2020; Accepted: December 28, 2020; Published: December 31, 2020

Copyright: () 2020 Guerra AB, et al. This is an open-access article distributed under the terms of the Creative Commons Attribution License, which permits unrestricted use, distribution and reproduction in any medium, provided the original author and source are credited.

\section{Case Report- 1}

One-month-old female with an uneventful pregnancy, term delivery, and unremarkable family history. She presented with hypopigmented, indurated, and retracted skin plaques with linear distribution along the lateral side of the right thigh (Figure 1). These lesions were noted since birth. Skin biopsy was performed and showed mild thickening and hyalinization of collagen fibers and normal epidermis. Orcein and Verhoeff stains revealed preserved elastic fibers (Figure 2). Due to the absence of skin inflammation both macroscopic and microscopically, a conservative wait-and-see approach was adopted. After three months of follow-up, spontaneous near-total remission of described lesions was reported. At twelve-month-old follow-up dermatology consultation, localized marmorated hypopigmentation persisted without cutaneous thickening. No pharmacological therapy was introduced to date. The infant was discharged with required lower limbs symmetry and joint mobility regular evaluation. No extracutaneous manifestations were described to date.

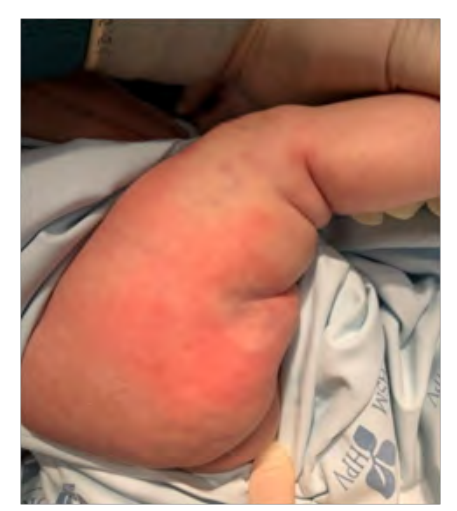

Figure 1: Hypopigmented, indurated and retracted skin plaques with linear distribution along the right thigh.

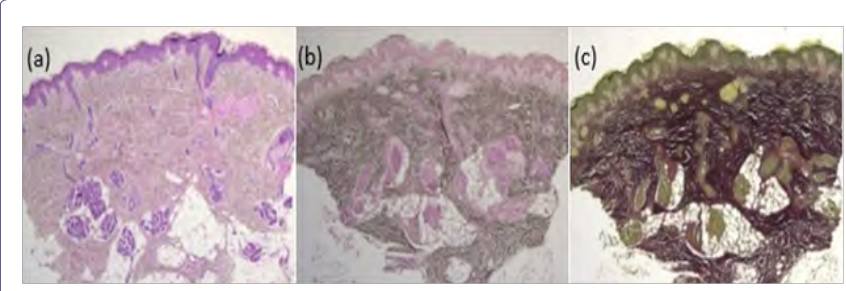

Figure 2: Hematoxylin and eosin (a) Orcein (b) Verhoeff stains (c) (25x). Mild thickening and hyalinization of collagen fibers with preserved elastic fibers.

\section{Case Report - 2}

A two-month-old male with an uneventful pregnancy and term delivery, previously healthy and without a family history of autoimmune diseases or connective tissue disorders, presented 
at birth with three grouped skin lesions on the gluteal region and right thigh. These were three rounded macules, measuring 15,20 and 8 millimeters, with central ivory induration and violaceous halo (Figure 3). The remaining physical examination was normal. Histopathological findings on skin biopsy performed at 2,5 months of age established the diagnosis of morphea (Figure 4). Topical treatment with tacrolimus twice daily was initiated with good response. After three months of treatment, only the smaller lesion persisted on the thigh with some pallor and lilac peripheral hue (Figure 5).

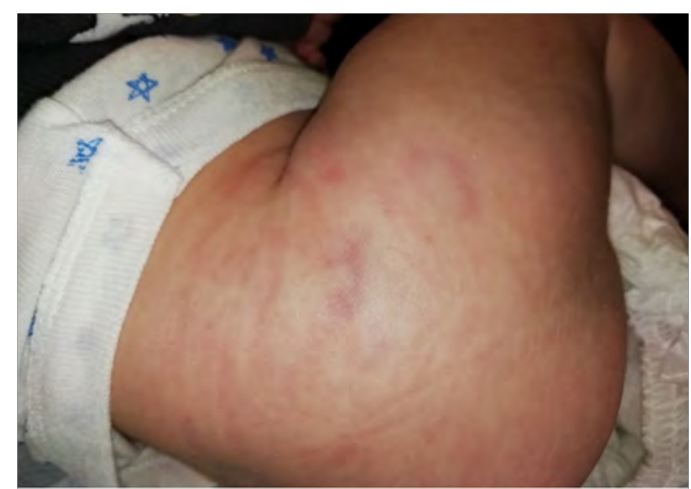

Figure 3: Threeoval circumscribed areas with central ivory color and violaceous halo.

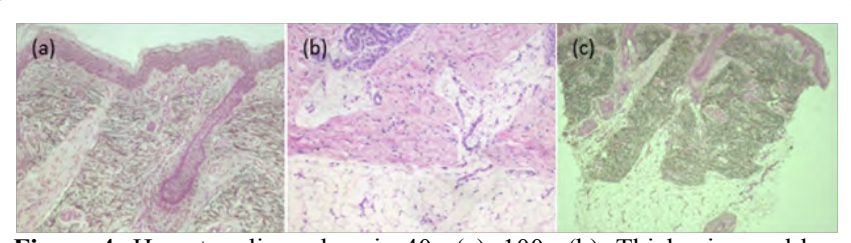

Figure 4: Hematoxylin and eosin 40x (a), 100x (b): Thickening and hyalinization of collagen fibers, with mild chronic infiltrate composed of lymphocytes and histiocytes. Orcein 40x (c): Preservation of elastic fibers.

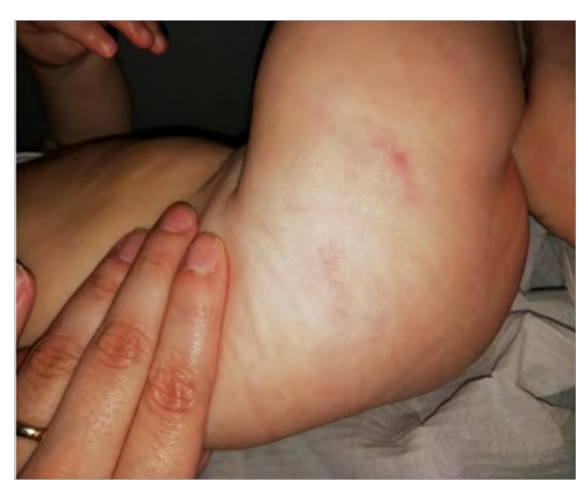

Figure 5: Improved skin lesions after treatment with tacrolimus.

\section{Discussion}

In literature, congenital morphea has been reported sparsely which leads to a lack of awareness of this condition and late diagnosis [3]. Morphea identification and classification may be difficult, particularly in small infants, because of its clinical spectrum and unknown progression [4]. About half of the patients present with an association of linear and plaque morphea [1]. Skin biopsy is very important to establish the diagnosis [2]. Extracutaneous manifestations are rarely associated with the described forms $[1,4]$. Nevertheless, lower limbs symmetry of length, creases, muscle, and joint mobility must be assessed in regular pediatric consultation, to diagnose and prevent orthopedic complications during the growth period [4,5]. Treatment is challenging and depends on location, severity, and disease activity. Spontaneous remission of sclerotic linear lesions was seen in case one. Topical treatment with calcineurin inhibitor (tacrolimus) twice daily was initiated on the second case with partial resolution of plaque lesions [2]. Despite the good prognosis of these mild forms of congenital morphea, prompt diagnosis is important to reduce longterm physical and psychological comorbidities [2].

\section{Declaration of Interest}

The Authors declare that there is no conflict of interest.

\section{References}

1. Torok KS (2012) Pediatric scleroderma-Systemic and localized forms. Pediatr Clin North Am 59: 381-405.

2. George R, George A, Kumar TS (2020) Update on management of morphea (Localized Scleroderma) in children. Indian DermatolOnline J 11: $135-145$.

3. Zulian F, C Vallongo, de Oliveira SKF, Punaro MG, Ros J, et al. (2006) Congenital localized scleroderma. J Pediatr 149: 248-251.

4. Mansour M, Wong CL, Zulian F, Li S, Morishita K, et al, (2018) Natural history and extracutaneous involvement of congenital morphea: Multicenter retrospective cohort study and literature review. Pediatric Dermatology 35: 761-768.

5. Najeeb N, Thomas J, Manoharan D (2015) Linear morphea in a child: A case report. Biomed Pharmacol J 8: 583-585. 


\section{Hif}

Advances In Industrial Biotechnology | ISSN: 2639-5665

Advances In Microbiology Research | ISSN: 2689-694X

Archives Of Surgery And Surgical Education | ISSN: 2689-3126

Archives Of Urology

Archives Of Zoological Studies | ISSN: 2640-7779

Current Trends Medical And Biological Engineering

International Journal Of Case Reports And Therapeutic Studies | ISSN: 2689-310X

Journal Of Addiction \& Addictive Disorders | ISSN: 2578-7276

Journal Of Agronomy \& Agricultural Science | ISSN: 2689-8292

Journal Of AIDS Clinical Research \& STDs | ISSN: 2572-7370

Journal Of Alcoholism Drug Abuse \& Substance Dependence | ISSN: 2572-9594

Journal Of Allergy Disorders \& Therapy | ISSN: 2470-749X

Journal Of Alternative Complementary \& Integrative Medicine | ISSN: 2470-7562

Journal Of Alzheimers \& Neurodegenerative Diseases | ISSN: 2572-9608

Journal Of Anesthesia \& Clinical Care | ISSN: 2378-8879

Journal Of Angiology \& Vascular Surgery | ISSN: 2572-7397

Journal Of Animal Research \& Veterinary Science | ISSN: 2639-375

Journal Of Aquaculture \& Fisheries | ISSN: 2576-5523

Journal Of Atmospheric \& Earth Sciences | ISSN: 2689-8780

Journal Of Biotech Research \& Biochemistry

Journal Of Brain \& Neuroscience Research

Journal Of Cancer Biology \& Treatment | ISSN: 2470-7546

Journal Of Cardiology Study \& Research | ISSN: 2640-768X

Journal Of Cell Biology \& Cell Metabolism | ISSN: 2381-1943

Journal Of Clinical Dermatology \& Therapy | ISSN: 2378-8771

Journal Of Clinical Immunology \& Immunotherapy | ISSN: 2378-8844

Journal Of Clinical Studies \& Medical Case Reports | ISSN: 2378-880

Journal Of Community Medicine \& Public Health Care | ISSN: 2381-1978

Journal Of Cytology \& Tissue Biology | ISSN: 2378-9107

Journal Of Dairy Research \& Technology | ISSN: 2688-9315

Journal Of Dentistry Oral Health \& Cosmesis | ISSN: 2473-6783

Journal Of Diabetes \& Metabolic Disorders | ISSN: 2381-201X

Journal Of Emergency Medicine Trauma \& Surgical Care | ISSN: 2378-8798

Journal Of Environmental Science Current Research | ISSN: 2643-5020

Journal Of Food Science \& Nutrition | ISSN: 2470-1076

Journal Of Forensic Legal \& Investigative Sciences | ISSN: 2473-733X

Journal Of Gastroenterology \& Hepatology Research | ISSN: 2574-2566
Journal Of Genetics \& Genomic Sciences | ISSN: 2574-2485

Journal Of Gerontology \& Geriatric Medicine | ISSN: 2381-8662

Journal Of Hematology Blood Transfusion \& Disorders | ISSN: 2572-2999

Journal Of Hospice \& Palliative Medical Care

Journal Of Human Endocrinology | ISSN: 2572-9640

Journal Of Infectious \& Non Infectious Diseases | ISSN: 2381-8654

Journal Of Internal Medicine \& Primary Healthcare | ISSN: 2574-2493

Journal Of Light \& Laser Current Trends

Journal Of Medicine Study \& Research | ISSN: 2639-5657

Journal Of Modern Chemical Sciences

Journal Of Nanotechnology Nanomedicine \& Nanobiotechnology | ISSN: 2381-2044

Journal Of Neonatology \& Clinical Pediatrics | ISSN: 2378-878X

Journal Of Nephrology \& Renal Therapy | ISSN: 2473-7313

Journal Of Non Invasive Vascular Investigation | ISSN: 2572-7400

Journal Of Nuclear Medicine Radiology \& Radiation Therapy | ISSN: 2572-7419

Journal Of Obesity \& Weight Loss | ISSN: 2473-7372

Journal Of Ophthalmology \& Clinical Research | ISSN: 2378-8887

Journal Of Orthopedic Research \& Physiotherapy | ISSN: 2381-2052

Journal Of Otolaryngology Head \& Neck Surgery | ISSN: 2573-010X

Journal Of Pathology Clinical \& Medical Research

Journal Of Pharmacology Pharmaceutics \& Pharmacovigilance | ISSN: 2639-5649

Journal Of Physical Medicine Rehabilitation \& Disabilities | ISSN: 2381-8670

Journal Of Plant Science Current Research | ISSN: 2639-3743

Journal Of Practical \& Professional Nursing | ISSN: 2639-568

Journal Of Protein Research \& Bioinformatics

Journal Of Psychiatry Depression \& Anxiety | ISSN: 2573-0150

Journal Of Pulmonary Medicine \& Respiratory Research | ISSN: 2573-0177

Journal Of Reproductive Medicine Gynaecology \& Obstetrics | ISSN: 2574-2574

Journal Of Stem Cells Research Development \& Therapy | ISSN: 2381-2060

Journal Of Surgery Current Trends \& Innovations | ISSN: 2578-7284

Journal Of Toxicology Current Research | ISSN: 2639-3735

Journal Of Translational Science And Research

Journal Of Vaccines Research \& Vaccination | ISSN: 2573-0193

Journal Of Virology \& Antivirals

Sports Medicine And Injury Care Journal | ISSN: 2689-8829

Trends In Anatomy \& Physiology | ISSN: 2640-7752

Submit Your Manuscript: https://www.heraldopenaccess.us/submit-manuscript 